\title{
Posttraumatic pseudoaneurysm of medial plantar artery in a child: treatment with percutaneous thrombin injection
}

\author{
Pseudoaneurisma pós-traumático de artéria plantar medial em criança: \\ tratamento percutâneo com injeção de trombina \\ Fabrício Neto Ladeira', Antônio Henrique de Souza Quintella', Leandro Toledo Carvalhido', \\ Liege Costa de Avelar Rezende ${ }^{1}$, Luciano Santa Bárbara de Abreu', Paula Cardoso Diniz', Francisco Lopes Pereira²
}

\begin{abstract}
Pseudoaneurysms of the medial plantar artery are rare. The authors describe a case of a pseudoaneurysm of the medial plantar artery of a child who had suffered a penetrating laceration injury. Diagnosis can be confirmed using Doppler ultrasound and magnetic resonance angiography. As an alternative to the conventional surgery technique, percutaneous Doppler ultrasound-guided thrombin injection is a safe and effective treatment.
\end{abstract}

Keywords: pseudoaneurysm; medial plantar artery; thrombin; Doppler ultrasound.

\section{Resumo}

O pseudoaneurisma da artéria plantar medial é raro. Os autores relatam um caso de pseudoaneurisma da artéria plantar medial após lesão perfurocortante em criança. O diagnóstico pode ser confirmado por ultrassom com Doppler e angiorressonância magnética. Em contraponto à técnica cirúrgica convencional, o tratamento pode ser feito de maneira efetiva e segura com a injeção percutânea de trombina assistida pelo ultrassom com Doppler.

Palavras-chave: pseudoaneurisma; artéria plantar medial; trombina; ultrassom Doppler. 


\section{INTRODUCTION}

Pseudoaneurysms are aneurysms whose walls are not comprised of the vessel's own parietal structures, which is what differentiates them from true aneurysms. They are very often the result of a communication with an artery after direct trauma, in which the lumen remains in contact with the pulsating hematoma, causing it to rupture. During its evolution, the clot that forms in the periphery of the hematoma tends to organize and, in conjunction with the cicatricial reaction of adjacent tissues, will form the walls of the aneurysm sac which, in turn, does not therefore have the elements that are characteristic of the artery wall. ${ }^{1,2}$

After the posterior tibial artery leaves the inferior retinaculum of the flexor muscles, it divides to form the medial plantar artery and the lateral plantar artery. The second of these is more developed and is accompanied by the plantar nerve. The medial plantar artery follows the medial plantar fascia and is accompanied by the medial plantar nerve. ${ }^{3}$

Vascular injuries leading to formation of a pseudoaneurysm in the plantar region of the foot are rare, despite the potential risk of localized trauma. ${ }^{4}$ Pseudoaneurysms of the lateral plantar artery have been reported after plantar fasciotomy, ${ }^{5,6}$ osteotomy of the calcaneus ${ }^{7}$, fracture of the calcaneus ${ }^{2}$ and after laceration of the foot in children. ${ }^{8,9}$ There are more publications dealing with pseudoaneurysms of the lateral plantar artery than of the medial plantar artery, probably because of its more superficial location. ${ }^{10}$

Posttraumatic pseudoaneurysms of the medial plantar artery are rare and little has been published about them, but there are reports of onset after percutaneous implantation of pins to treat a Lisfranc fracture-luxation, ${ }^{11}$ and after lacerating trauma of the foot. ${ }^{10}$ Time to diagnosis is variable and may be anything from 3 days to 5 years after the trauma. ${ }^{12}$ In this paper we report on the case of a medial plantar artery pseudoaneurysm secondary to a penetrating laceration trauma in a child.

\section{CASE REPORT}

The patient was an 8-year-old Caucasian male who suffered a trauma to the plantar surface of the right foot, caused by a sharp object (broken glass). The wound was sutured, bleeding was apparently controlled and there was no evidence of any residual foreign body.

Forty-five days later, the patient suffered swelling and pain in the right plantar foot that was exacerbated by bearing weight, walking and compression.
Physical examination revealed a pulsating mass, with a diameter of approximately $3 \mathrm{~cm}$. The patient reported pain in response to palpation and the surrounding area was hyperemic, but there was no sign of active infection or bleeding. Femoral and distal pulses were present, there was no cyanosis, trophic lesions or decrease in capillary perfusion. Laboratory test results were within normal limits. Both sensitivity and motricity were preserved.

Magnetic resonance angiography of the right foot showed a pseudoaneurysm with a rounded shape, regular outline and well-defined limits located in the plantar region, between the abductor muscles of the fifth toe and the short flexor of the toes. After intravenous administration of contrast medium, the pseudoaneurysm was easily visible and measured at around $24 \times 21 \times 21 \mathrm{~mm}$. Deeper, the structure extended to the plantar neurovascular bundle and, following the perforation injury to the plantar fascia, there was edema of the short flexor muscles of the toes and of the abductor of the fifth toe, reaching the plantar fat pad and the cutaneous surface. All bones, tendons and ligaments were spared (Figure 1).

These findings were corroborated by a Doppler ultrasound, which, in addition to the anatomic details, also showed the dynamics of the medial plantar artery pseudoaneurysm (Figure 2).

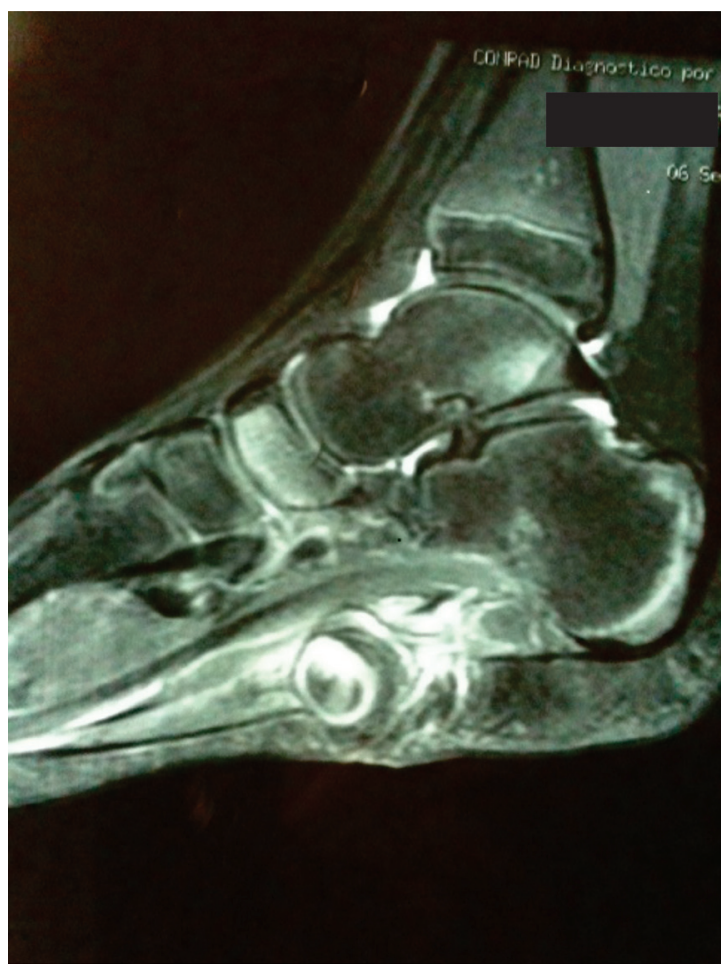

Figure 1. Magnetic resonance image showing the contrast highlighting the plantar region, suggesting a pseudoaneurysm. 


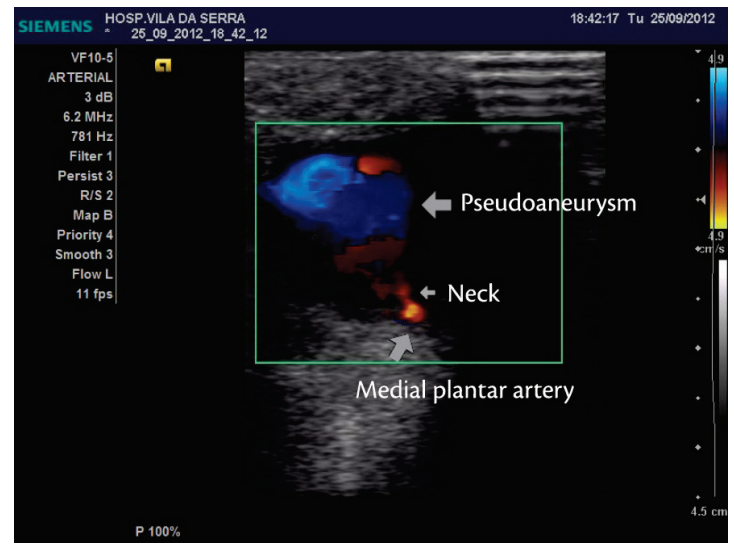

Figure 2. Vascular echography scan, showing the pseudoaneurysm and its neck in the plantar region of the foot.

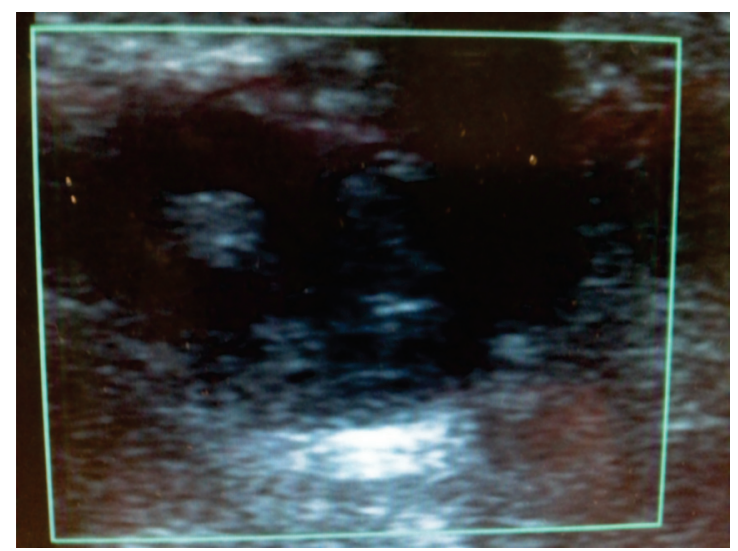

Figure 3. Image of pseudoaneurysm immediately after percutaneous thrombin injection, showing no blood flow in the interior
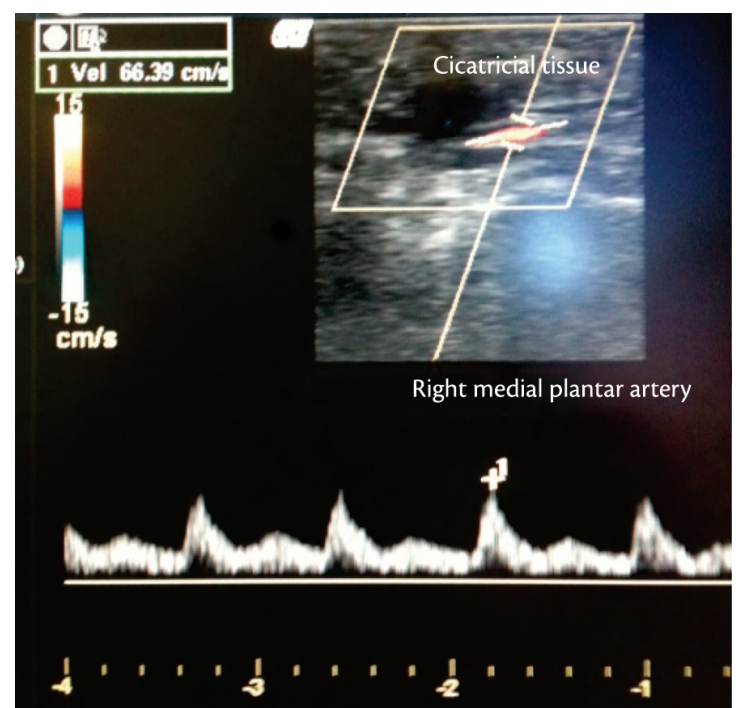

Figure 4. Eight-month follow-up control vascular echography scan, showing a completely thrombosed pseudoaneurysm in regression.
The plantar pseudoaneurysm was treated with a Doppler ultrasound guided percutaneous injection of 300 units of dilated thrombin under sedation and local anesthetic. The thrombin was injected carefully until the flow inside the pseudoaneurysm was observed to cease. The thrombin dose administered was sufficient to totally and instantaneously occlude the lesion while maintaining patency of the native artery (Figure 3). The patient was already able to walk with no limitations on the third day after treatment and was free from complications or relapse at 8 months' follow-up (Figure 4).

\section{DISCUSSION}

Some pseudoaneurysms can resolve spontaneously, ${ }^{13}$ but early diagnosis and treatment are nevertheless recommended to avoid potential harm; such as motor disorders or circulatory problems, ruptures and compression of bony structures, veins or adjacent nerves, leading to tarsal tunnel syndrome. ${ }^{10,14,15}$

Detailed clinical history taking and physical examination are of fundamental importance for early diagnosis and should take account of time and mechanism of trauma. ${ }^{8,10,16}$ Pain, edema and hematoma are the initial symptoms of pseudoaneurysms. Persistence of pain after the trauma, a pulsating mass, systolic murmur, neurological signs and a fall in hemoglobin with no other obvious cause should suggest a diagnostic hypothesis of pseudoaneurysm. ${ }^{10,12}$

Imaging exams are indispensable to confirm and study these lesions. Diagnosis can be made by Doppler ultrasound, angiography and magnetic resonance angiography., ${ }^{4}$.12 Angiography is excellent for studying arterial anatomy, but is invasive and demands iodine contrast. On the other hand, Doppler ultrasound is a noninvasive method that is a valuable tool for studying lesions in extremities, but it is operator-dependent. Finally, magnetic resonance angiography offers higher spatial resolution of the lesion and higher sensitivity and specificity than angiography for studying the arterial tree and detecting peripheral vascular disease. ${ }^{4,17,18}$

Surgical treatment of pseudoaneurysms may require ligature or arterial resection and repair with end-to-end anastomosis or vein grafts (generally from the great saphenous vein). ${ }^{10,15}$ Damage to adjacent structures and bleeding are possible complications of these techniques.

Non-surgical treatments, considered minimally invasive, can be accomplished using coils or percutaneous injection of thrombin or sclerosant 
substances (ethanol, for example), and have proven effective for resolving pseudoaneurysms. ${ }^{15,19,20}$

Endovascular treatments have also been used successfully, ${ }^{10}$ but the inherent risks of these techniques must be considered: hemorrhage, pseudoaneurysm at the puncture site, ischemic complications and adverse reactions to the iodine contrast medium.

Ultrasound compression of the pseudoaneurysm neck alone can be technically challenging and uncomfortable for the patient, requiring compression times that vary from 10 to 300 minutes. In contrast, percutaneous ultrasound-guided thrombin injection requires simple compression of the aneurysm sac neck and offers rapid thrombosis. ${ }^{21}$

Thrombin is a powerful coagulation induction agent that acts by converting fibrinogen in to fibrin, but dosages are not very well defined in the literature. ${ }^{21}$ It is very much worth employing realtime monitoring as the thrombin is injected into the aneurysm sac, using color flow ultrasound..$^{22}$ The injection should be stopped as soon as flow into the aneurysm sac has ceased; generally occurring in a few seconds. If the injection is continued after flow has ceased within the aneurysm sac, there is a greater risk of thrombosis of the native artery caused by retrograde flow, exposing the artery to thrombin. ${ }^{21}$

A number of factors can impact on the method's safety and efficacy. Firstly, it appears that if the needle is positioned superficially within the centre of the aneurysm sac, at the pole most distant from the communicating orifice, clots are more likely to form and then migrate in the direction of the aneurysm neck. ${ }^{21,23}$ It is therefore preferable to inject into a region in which flow is predominantly inward, in order to minimize the risk of arterial embolism. ${ }^{23}$

It appears that complications related to thrombin injections are infrequent, with few reported cases of local infection, thrombosis and/or arterial thromboembolism or allergic reactions to thrombin. The most threatening of the known complications described in literature are arterial thrombosis and/ or thromboembolism, which can be prevented by avoiding injecting the thrombin close to or at the pseudoaneurysm neck..$^{21,23}$

Nowadays noninvasive imaging exams offer excellent opportunities to study the lesion at low risk to the patient. While there is evidence that Doppler ultrasound-guided percutaneous thrombin injection offers the chance of safe, effective and minimally invasive treatment, detailed workup and rigorous attention to technical details play a fundamental role in successful treatment outcomes.

\section{CONCLUSIONS}

The Doppler ultrasound-assisted percutaneous thrombin injection technique used in this case of posttraumatic medial plantar artery pseudoaneurysm led to total resolution of the lesion and relief from symptoms. After eight months' follow-up, there have been no signs of complications or relapse of the lesion and the patient remains entirely asymptomatic. We can therefore conclude, in consonance with published data, that this technique should be considered for treatment of similar cases.

\section{REFERENCES}

1. Brito CJ, Filho VLF, Silva RM. Aneurismas arteriais. In: Brito CJ, editor. Cirurgia Vascular, cirurgia endovascular, angiologia. 2. ed. Livraria e Editora Revinter Ltda; 2008. p. 501-7.

2. Agarwal M, Harkless L, Hagino RT, Toursarkissian B. Lateral plantar artery aneurysm: a case report. J Am Podiatr Med Assoc. 2007;97(6):480-2. PMid:18024844. [citado 2013 ago. 8]. http:// www.japmaonline.org/content/97/6/480.long.

3. Silva JLCN. Anatomia Médico-Cirurgica do Sistema Vascular. In: Brito C), editor. Cirurgia Vascular, cirurgia endovascular, angiologia. 2. ed. Livraria e Editora Revinter Ltda; 2008. p. 25-72.

4. Murakami AM, Chang A, Foo LF. Traumatic Lateral Plantar Artery Pseudoaneurysm and the Use of Time-Resolved MR Angiography. HSS J. 2010 Sept; 6(2):214-8. PMid:21886538 PMCid:PMC2926369. http://dx.doi.org/10.1007/s11420-010-9170-3

5. Nierenberg G, Hoffman A, Engel A, Stein H. Pseudoaneurysm with an arteriovenous fistula of the tibial vessels after plantar fasciotomy: a case report. Foot Ankle Int. 1997;18(8):524-5. PMid:9278750. http://dx.doi.org/10.1177/107110079701800814

6. Gentile AT, Zizzo CJ, Dahukey A, Berman SS. Traumatic pseudoaneurysm of the lateral plantar artery after endoscopic plantar fasciotomy. Foot Ankle Int. 1997 Dec;18(12):821-2. PMid:9429886. http://dx.doi.org/10.1177/107110079701801212

7. Ptaszek AJ, Aminian A, Schneider JR, Milos S. Lateral plantar artery pseudoaneurysm after calcaneal osteotomy: a case report. Foot Ankle Int. 2006;27(2):141-3. PMid:16487469. http://dx.doi. org/10.1177/107110070602700213

8. Thornton BP, Minion DJ, Quick R, Vasconez HC, Endean ED. Pseudoaneurysm of the lateral plantar artery after foot laceration. J Vasc Surg. 2003;37(3):672-5. PMid:12618709. http://dx.doi. org/10.1067/mva.2003.31

9. 9 Economou P, Paton R, Galasko CS. Traumatic pseudoaneurysm of the lateral plantar artery in a child. J Pediatr Surg. 1993;28(4):626. http://dx.doi.org/10.1016/0022-3468(93)90674-A

10. Park SE, Kim JC, Ji JH, Kim YY, Lee HH, Jeong JJ. Post-traumatic pseudoaneurysm of the medial plantar artery combined with tarsal tunnel syndrome: two case reports. Arch Orthop Trauma Surg. 2013 Mar;133(3):357-60. PMid:23242453. http://dx.doi. org/10.1007/s00402-012-1672-7

11. Baeza L, Farrell ED, Salgado CJ. Medial plantar artery pseudoaneurysm following percutaneous pinning for Lisfranc fracture-dislocation. J Am Podiatr Med Assoc. 2009;99(1):58-60. Pmid:19141724. [citado 2013 ago. 8]. http://www.japmaonline. org/content/99/1/58.full.pdf+html.

12. Irarrazaval CA, Gross RS, Maritano AS, Diez CS. Posttraumatic Pedal Artery Pseudoaneurysm: A Case Report. Case Rep Vasc 
Med. 2012; 2012:234351. PMCid:PMC3420662. http://dx.doi. org/10.1155/2012/234351

13. Upponi SS, Solan M. Spontaneous resolution of a traumatic false aneurysm of the peroneal artery. Injury. 1998;29:787-8. http:// dx.doi.org/10.1016/S0020-1383(98)00156-9

14. Matsushita M, Nishikimil N, Sakurai T, Nimura Y. Pseudoaneurysm of the popliteal artery caused by exostosis of the femur: case report and review of the literature. J Vasc Surg. 2000;32:201-4. PMid:10876225. http://dx.doi.org/10.1067/mva.2000.105679

15. Spratt EM, Doran ML, Baird RJ. False aneurysms in the lower extremity. Surg Gynecol Obstet. 1967;124:562-6. PMid:6018518. [citado 2013 ago. 8]. http://www.nlm.nih.gov/medlineplus/ aneurysms.html.

16. Darwish A, Ehsan O, Marynissen H, Al-Khaffaf H. Pseudoneurysm of the anterior tibial artery after ankle arthroscopy. Arthroscopy. 2004;20:63-64. PMid:6018518. [citado 2013 ago. 8]. http://www. arthroscopyjournal.org/article/S0749-8063(04)00554-7/fulltext.

17. Sueyoshi E, Sakamoto I, Matsuoka Y, et al. Aortoiliac and lower extremity arteries: comparison of three-dimensional dynamic contrast-enhanced subtraction MR angiography and conventional angiography. Radiology. 1999;210(3):683-8. PMid:10207467. http://dx.doi.org/10.1148/radiology.210.3.r99fe22683

18. Koelemay MJ, Lijmer JG, Stoker J, Legemate DA, Bossuyt PM. Magnetic resonance angiography for the evaluation of lower extremity arterial disease: a meta-analysis. JAMA. 2001;285(10):1338-45. PMid:11255390. http://dx.doi.org/10.1001/ jama.285.10.1338

19. Cho SE, Kim DH, Jeong ST, et al. Therapeutic embolization for pseudoaneurysm of the anterior tibial artery after tibial nailing. J Korean Orthop Assoc. 2010;45:238-242. http://dx.doi. org/10.4055/jkoa.2013.48.3.240

20. Walker TG, Geller SC, Brewster DC. Transcatheter occlusion of a profunda femoral artery pseudoaneurysm using thrombin. AJR. 1987;149:185-186. PMid:3495980. http://dx.doi.org/10.2214/ ajr.149.1.185

21. D'Achille A, Sebben RA, Davies RP. Percutaneous ultrasound-guided thrombin injection for coagulation of post-traumaticpseudoaneurysms. Australas Radiol. 2001 May;45(2):218-21. PMid:11380368. http://dx.doi. org/10.1046/j.1440-1673.2001.00906.x

22. Kang SS, Labropoulos N, Mansour MA, Baker WH. Percutaneous ultrasound guided thrombin injection: A new method for treating postcatheterization femoral pseudoaneurysms. J Vasc Surg. 1998;6:1032-8. http://dx.doi.org/10.1016/S0741-5214(98)70006-0

23. Gioppato $S$, Munhoz A, Marins $M$, et al. Injeção de trombina guiada por ultrassom no tratamento de pseudoaneurisma da artéria femoral após procedimento percutâneo em pacientes com síndrome coronária aguda. Rev Bras Cardiol Invasiva. 2010;18(2):165-70. http://dx.doi.org/10.1590/ S2179-83972013000100006

\section{Correspondence Francisco Lopes Pereira Serviço de Cirurgia Vascular-HMOB Rua Formiga, 50, São Cristóvão CEP 31210-780 - Belo Horizonte (MG), Brazi Fone: +55 (31) 8848-5888 E-mail:frankypereira@hotmail.com}

Author's information FNL é cirurgião vascular do Hospital Vila da Serra (MG) e Hospital Odilon Behrens (BH); coordenador dos serviços de residência médica em cirurgia vascular do Hospital Odilon Behrens (BH) e de especialização em cirurgia vascular do Hospital Vila da Serra (MG); ecografista vascular do Laboratório Hermes Pardini (BH). AHSQ é coordenador dos serviços de cirurgia vascular dos Hospitais Vila da Serra (MG) e Universitário São José (BH) LCAR é cirurgiã vascular do Hospital Vila da Serra (MG).

LTC é cirurgião vascular do Hospital universitário São José (BH) e ecografista vascular do Hospital Vila da Serra (MG).

LSBA é médico especializando em cirurgia vascular do Hospital Vila da Serra (MG)

PCD é médica especializando em cirurgia vascular do Hospital Vila da Serra (MG)

FLP é médico residente em cirurgia vascular do Hospital Odilon Behrens (BH).

Author contributions Conception and design: FNL Analysis and interpretation: FNL, FLP Data collection: FNL, AHSQ, LTC, LCAR, PCD Writing the article: FNL, LSBA, FLP Critical revision of the article: FLP Final approval of the article*: FNL, AHSQ, LTC, LCAR, LSBA, PCD, FLP Statistical analysis: N/A Overall responsibility: FNL Financial support: None

*All authors have read and approved of the final version of the article submitted to I Vasc Bras. 